\title{
Stadiochilus R. M. Sm. (Zingiberaceae: Zingibereae), a new generic record for India
}

\author{
D. K. Roy ${ }^{1,3 *}$, R. Lytan $^{2,4}$, D. L. Biate ${ }^{2,5}$, N. Odyuo ${ }^{2,6}$ \\ ${ }^{1}$ Department of Botany, Birjhora Mahavidyalaya (Degree Science College), Bongaigaon, Assam, 783380, India \\ ${ }^{2}$ Botanical Survey of India, Eastern Regional Centre, Shillong, Meghalaya, 793003, India \\ ${ }^{3}$ E-mail: dilipbsierc@gmail.com; ORCID iD: https://orcid.org/0000-0002-2400-5928 \\ ${ }^{4}$ ORCID iD: https://orcid.org/0000-0002-4182-8977 \\ ${ }^{5}$ ORCID iD: https://orcid.org/0000-0002-8641-4436 \\ ${ }^{6}$ ORCID iD: https://orcid.org/0000-0001-9711-1150 \\ *Corresponding author
}

Keywords: flora of India, floristic record, ginger, Stadiochilus burmanicus, Zingiberaceae.

Summary. The monotypic ginger genus Stadiochilus R. M. Sm. with S. burmanicus R. M. Sm. earlier known from Myanmar is reported here as a new record for India from the state of Nagaland. A detailed taxonomic description along with photographic illustrations of S. burmanicus is given. For conservation purposes, the IUCN status of this species has been evaluated as Endangered. The present field study ascertained that extraction of timber and non-timber forest products, forest fires and shifting cultivation are the major threats to the species in the locality in Nagaland reported here.

\section{Stadiochilus R. M. Sm. (Zingiberaceae: Zingibereae) - новый род во флоре Индии}

\author{
Д. К. Рой ${ }^{1}$, Р. Литан ${ }^{2}$ Д. Л. Биате ${ }^{2}$ Н. Одюо 2 \\ ${ }^{1}$ Кафедра ботаники, Бирджхора Махавидьялая (Высший научный колледж), Бонгайгаон, Ассам, 783380, Индия \\ ${ }^{2}$ Ботаническое обследование Индии, Восточный региональный центр, Шиллонг, Мегхалая, 793003, Индия
}

Ключевые слова: имбирные, флора Индии, флористическая находка, Stadiochilus burmanicus, Zingiberaceae.

Аннотация. Единственный вид рода Stadiochilus R. M. Sm. - S. burmanicus R. M. Sm. (сем. Имбирные Zingiberaceae), ранее известный только из Мьянмы, приводится в качестве новинки для Индии из штата Нагаленд. Представлены подробное таксономическое описание и фотоиллюстрации S. burmanicus. Природоохранный статус этого вида по критериям МСОП оценивается как находящийся под угрозой исчезновения. Проведенное полевое исследование подтвердило, что вырубка леса и сбор недревесных лесных ресурсов, лесные пожары и подсечное земледелие являются основными факторами сокращения численности S. burmanicus в штате Нагаленд. 


\section{Introduction}

Stadiochilus R. M. Sm. (Zingibereae, Zingiberoideae, Zingiberaceae) is a monotypic genus, its only species, S. burmanicus R. M. Sm., was based on collections made from 1961-1962 by J. Keenan, Yun Aung and Tha from Hpuginhku village under Sumprabum Sub-Division in the state of Kachin, Myanmar (Smith, 1980). The genus is poorly known and has not been treated in a phylogenetic analysis of Zingiberaceae (Kress et al., 2002; Larsen, 2005). So far, Stadiochilus has only been known from Myanmar (Smith, 1980; Larsen, 2005).

During field exploration in December 2018 in Woashu Village, Tuengsang district, Nagaland, in connection with the Approved Research Programme "State flora of Nagaland, India" of Botanical Survey of India, Eastern Regional Centre, Shillong, Meghalaya (India), some unknown ginger rhizomes were collected along with field notes and taken for cultivation in the garden of Botanical Survey of India. In December 2019, this accession started blooming on terminal inflorescences. The flowers were dissected, and detailed morphological study of the living plant materials was carried out. Afterward, consultation of available literature (Smith, 1980; Larsen, 2005) revealed that the plant specimen belonged to Stadiochilus burmanicus, a species hitherto not recorded from India. Thus, the present collection of this species in Nagaland forms the first report of the monotypic ginger genus Stadiochilus from India. A detailed taxonomic description along with photographs (Figs. 1-3) of S. burmanicus is provided here. The conservation status of the species is evaluated following IUCN guidelines.

\section{Materials and Methods}

Collection, pressing and preparation of herbarium specimen of the ginger plant were done in accordance with conventional herbarium techniques (Jain, Rao, 1976). Taxonomic measurements and descriptions of each plant part were based on living materials cultivated in the garden of Botanical Survey of India, Eastern Regional Centre, Shillong, Meghalaya (India). Microscopic details were observed using an Olympus SZ2-ILST stereo-zoom microscope (Olympus, Tokyo, Japan) and a Carl Zeiss EVO 18 (special edition) scanning electron microscope (Zeiss, Oberkochen, Germany) and photographed with a Nikon Cool pix P520 (Nikon, Tokyo,
Japan). The pollen grains and ovules for scanning electron microscopy (SEM) were collected from the living plants. The freshly collected pollen grains and ovules were mounted on SEM stubs with a conductive adhesive tab. Then, the mounted samples were coated with gold using a SC7620 Sputter Coater (United Kingdom) and finally, the metal coated un-desiccated samples were examined in scanning electron microscope. Finally, the taxonomic identity of the plant was confirmed to be Stadiochilus burmanicus after comparing our morphological description with the protologue (Smith, 1980) and the type specimen of $S$. burmanicus J. Keenan, U Tun Aung et U Tha Hla, No. 3733 housed in E (Royal Botanic Garden Edinburgh. URL: https://data.rbge. org.uk). A voucher specimen of the plant N. Odyuo and D. K. Roy 128935 deposited in the Herbarium of the Botanical Survey of India, Eastern Regional Centre, Shillong (ASSAM). The conservation status of this species was evaluated according to the IUCN Red List Categories and Criteria (IUCN, 2012).

\section{Results}

Stadiochilus R. M. Sm. 1980, Notes Roy. Bot. Gard. Edinburgh 38(1): 15.

Type species: Stadiochilus burmanicus R. M. Sm.

Stadiochilus burmanicus R. M. Sm. 1980, Notes Roy. Bot. Gard. Edinburgh 38(1): 15.

Holotype: [Myanmar] "Kachin State, Sumprabum Sub-Division, Eastern approaches from Sumprabum to Kumon Range. Surrounds of Hpuginhku village. 1700 m. II 1962. J. Keenan, U. T. Aung and U. T. Hla 3733" (E00102797; https:// data.rbge.org.uk).

Description. Terrestrial or epiphytic, perennial rhizomatous herb. Rhizomes greyish brown externally, sheathed, creamy-white inside, $2-2.5 \mathrm{~cm}$ in diam., mildly aromatic. Roots fleshy, up to $50 \mathrm{~cm}$ long and up to $1 \mathrm{~cm}$ in diam., creamy white. Pseudostems slanting, up to $100 \mathrm{~cm}$ tall, $0.8-1 \mathrm{~cm}$ in diam.; leaf sheaths pubescent, ca. $1.5 \mathrm{~cm}$ wide, with purple tinge along margins. Ligule ovate-lanceolate, 2-2.5 cm long, 0.5-0.7 cm wide, entire, sparsely hairy, purple. Leaves shortly petiolate; petiole $0.3-1 \mathrm{~cm}$ long, sparsely pubescent; lamina ovatelanceolate to elliptic-lanceolate, $4-30 \times 3.5-10 \mathrm{~cm}$, glabrous on both surfaces, dark green above, pale green beneath, entire along margins, base attenu- 
ate, apex acuminate. Inflorescence a terminal spike, 10-12 cm long, densely flowered; peduncle $1 \mathrm{~cm}$ long, $0.5 \mathrm{~cm}$ wide, enclosed by two, $3-7 \mathrm{~cm}$ long sheaths; rachis densely hairy. Bracts lanceolate, $2.5-4 \mathrm{~cm}$, pink, hairy outside, glabrous inside, acute at apex, persistent, each with a single flower. Bracteoles tubular, $1.5-3 \mathrm{~cm}$ long, similar to bracts. Calyx tubular, 3-4 cm long, pink, sparsely hairy outside, glabrous inside, apex acute. Corolla pink, tube $2-3.5 \mathrm{~cm}$ long, slender, with a longitudinal groove on internal surface which holds the filament; lobes linear-lanceolate, $2.8-3.5 \mathrm{~cm}$ long, glabrous. Lateral staminodes entirely absent. Labellum creamywhite, erect, folded around filament, ovate-elliptic, $2.6-3.8 \mathrm{~cm}$ long, ca. $1.2 \mathrm{~cm}$ wide when unfolded, apex weakly bilobed; sinus $1-1.3 \mathrm{~cm}$ long. Stamen exserted, straight; filament creamy white, $4-4.2 \mathrm{~cm}$ long, terete, with a longitudinal groove which holds the style; anther oblong, 4-5 mm long, ca. $2 \mathrm{~mm}$ wide, basifixed, glabrous; pollen grains light yellow, spheroidal, 47-53 $\mu \mathrm{m}$ in diam., inaperturate, with psilate exine ornamentation. Ovary $2 \mathrm{~mm}$ in diam., silky hairy, trilocular with numerous ovules on axile placentae; ovules light pink, semi-globose, 290-310 $\mu \mathrm{m}$ in diam., glabrous. Style filiform; stigma cupshaped, exserted from anther theca, green, ciliate along margins. Epigynous glands 2, slender, $2.5 \mathrm{~mm}$ long, creamy white. Fruits not seen. Flowering December to March.

Distribution. India (Nagaland, currently reported locality), Myanmar (Kachin State, the earlier record).

Specimens examined. India: "Nagaland: Tuengsang district, Woashu Village. 13 I 2020 ex hort. in Garden of Botanical Survey of India (eastern regional Centre, Meghalaya, east Khasi Hills, Shillong, Woodland Campus). N. Odyuo, D. K. Roy 128935" (ASSAM!). Myanmar: "Kachin State: Sumprabum Sub-Division, Eastern approaches from Sumprabum to Kumon Range, surrounds of Hpuginhku village. III 1962. J. Keenan, U. T. Aung, U. T. Hla 3801" (E; image 00499777!); "In the same place. 13 I 1962. J. Keenan, U. T. Aung, U. T. Hla 3250" (E; image 00102795!); "In the same place. 31 XII 1961. J. Keenan, U. T. Aung, U. T. Hla 3107" (E; image 00102796!); "In the same place. I 1962. J. Keenan, U. T. Aung, U. T. Hla 3230” (E; image 00499776!); "In the same place. 17 I 1962.
J. Keenan, U. T. Aung, U. T. Hla 3269" (E; image 00102794!); "Putao District, Naungmung Township, buffer zone of Hkakaborazi National Park, between Golle village and Gatthu village, $581 \mathrm{~m} .10$ X 2015. K. Armstrong, D. Little, M. M. San, Z. N. Tun, P. S. Aung, A. Syn, A. Bai 1363" (NY; image NY02649132!).

Conservation. The species is known from 3 localities, the type locality, the locality of Armstrong et al. 1363 (E, NY), and the locality in Nagaland reported here. The extent of occurrence (EOO) is estimated to be $10623 \mathrm{~km}^{2}$ and the area of occupancy (AOO) to be $12 \mathrm{~km}^{2}$. Thus, on the basis of the IUCN (2012) classification criteria, Stadiochilus burmanicus is assessed as Endangered (EN B2ab (ii, iii)), because the AOO is less than $500 \mathrm{~km}^{2}$, the number of locations is less than 5 and a continuing decline in the AOO and quality of the habitat can be observed or inferred.

\section{Discussion}

The morphological description of the Indian specimen of Stadiochilus burmanicus matches the protologue well. We did not find any major differences while comparing our material with the Burmese collections. We could not determine the fruit characters for the species, which were also omitted from the protologue. Hand-pollination was carried out, while the plants bloomed in cultivation, but did not result in fruiting. The restrictions put in place because of the Covid-19 pandemic meant that we could not revisit the present reported locality in Nagaland to ascertain the population status of the species in wild, but based on our earlier field study it is presumed that the species is not secure in the reported locality owing to extraction of timber and non-timber forest products, forest fires and shifting cultivation.

\section{Acknowledgement}

We are grateful to Dr. A. A. Mao, Director, Botanical Survey of India, Kolkata, for the facilities and encouragement. DKR is highly thankful to Dr. Khanindra Kr. Sarma, Principal, Birjhora Mahavidyalaya (Degree Science College), Bongaigaon, Assam, for encouragement. 



Fig. 1. Stadiochilus burmanicus: A - Habit; B-C - Inflorescence; D - Ligule; E - Leaf blade, lower surface; F - Leaf blade, upper surface; $\mathrm{G}-$ Rhizomes. Photographed by D. K. Roy, in cultivation. 


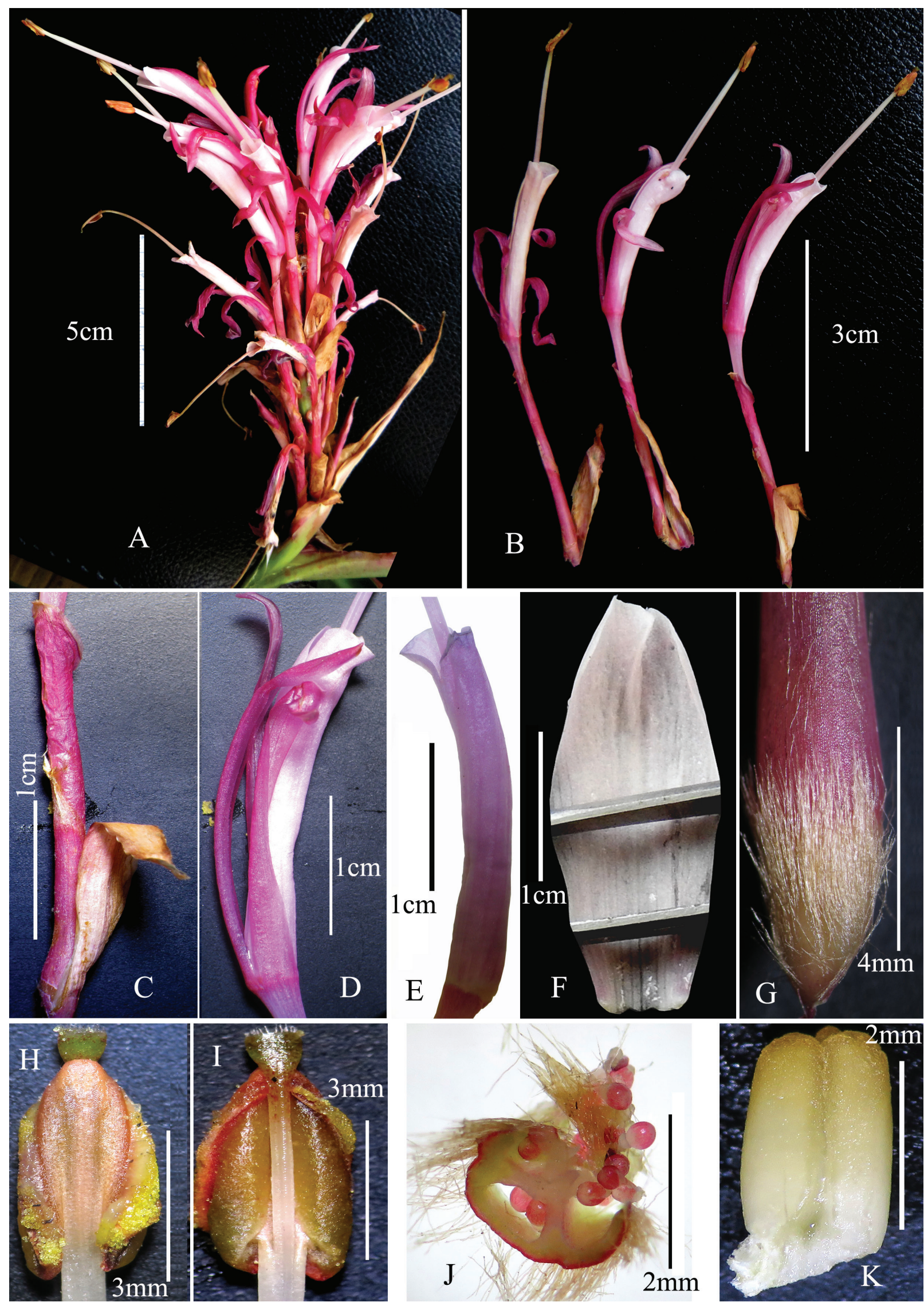

Fig. 2. Stadiochilus burmanicus: A - Inflorescence; B - Flowers, with bracts; C - Corolla tube, with bract, bracteole and calyx; D - Corolla lobes and labellum (folded); E - Labellum (folded); F - Labellum (unfolded); G - Ovary; $\mathrm{H}$ - Anther (dorsal view), with stigma; I - Anther (ventral view), with stigma; J - Transverse section of ovary, showing the ovules; K - Epigynous glands. Photographed by D. K. Roy, in cultivation. 

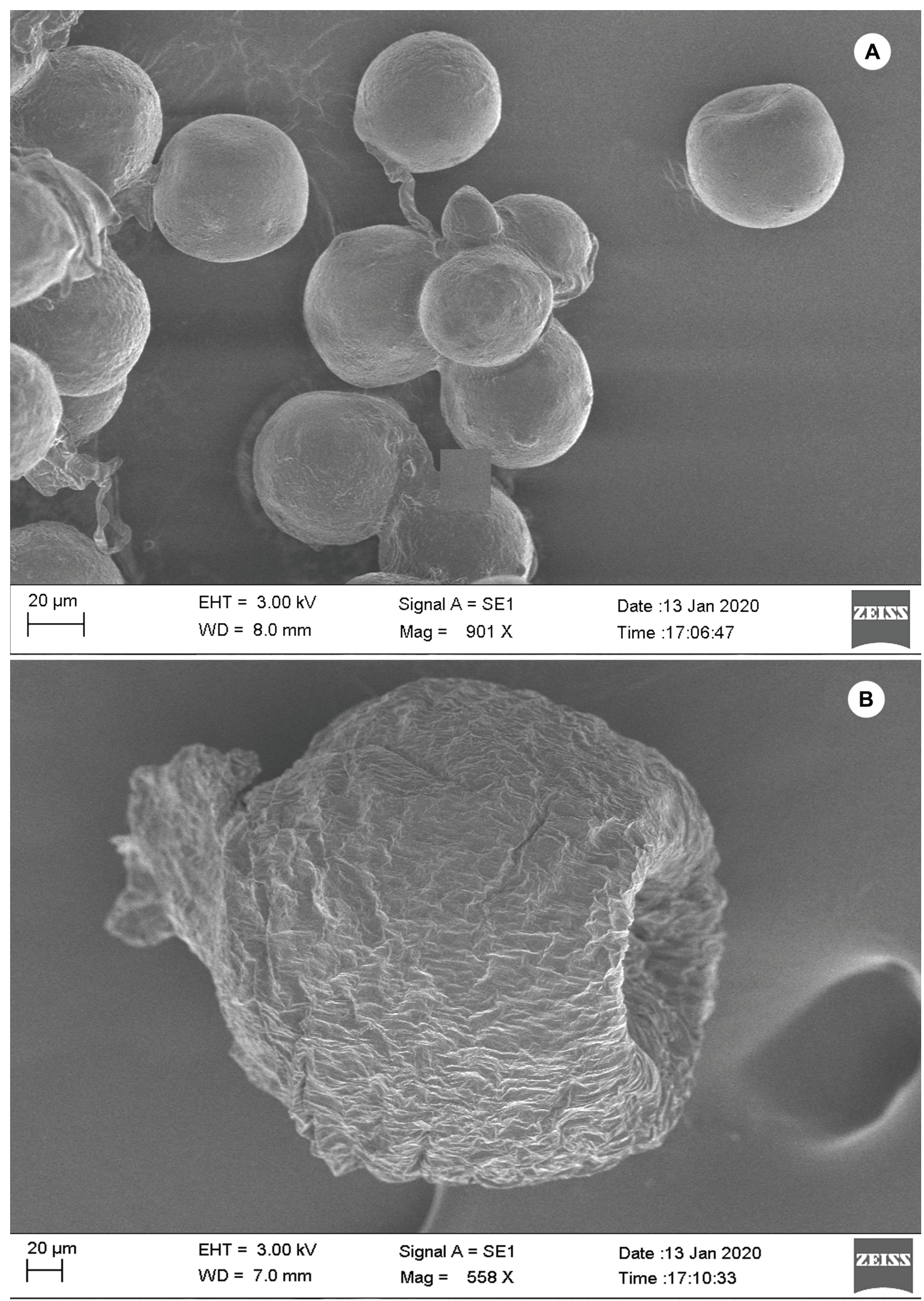

Fig. 3: Stadiochilus burmanicus. SEM micrographs - A - Pollen grains; B - Ovule. SEM made by D. K. Roy. 


\section{References}

IUCN. 2012. IUCN Red List Categories and Criteria: Version 3.1. Second edition. Gland, Switzerland and Cambridge, UK: IUCN. iv + 32 pp.

Jain S. K., Rao R. R. 1976. A handbook of Field and Herbarium Methods. New Delhi: Today and Tomorrow's Printer Publisher. Pp. 1-157.

Kress W. J., Price L. M., Williams K. J. 2002. The phylogeny and a new classification of the gingers (Zingiberaceae): Evidence from molecular data. Am. J. Bot. 89: 1682-1696.

Larsen K. 2005. Distribution patterns and diversity centres of Zingiberaceae in SE Asia. Biol. Skr. 55: 219-228.

Royal Botanic Garden Edinburgh. URL: https://data.rbge.org.uk/search/herbarium/ (Accessed 08 September 2021).

Smith R. M. 1980. A new genus of Zingiberaceae from N. Burma. Notes Roy. Bot. Gard. Edinburgh 38(1): $13-17$. URL: https://archive.org/details/notes-from-royal-botanic-garden-edinburgh-38-001-013-017 